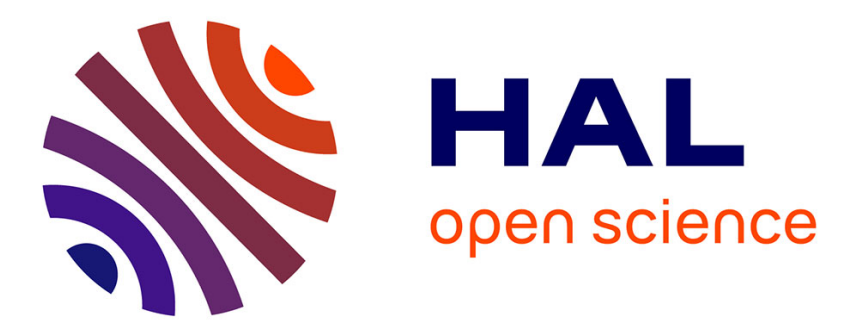

\title{
Genetics and taxonomy of Chilean smooth-shelled mussels, Mytilus spp. (Bivalvia: Mytilidae)
}

Philippe Borsa, Vincent Rolland, Claire Daguin-Thiébaut

\section{To cite this version:}

Philippe Borsa, Vincent Rolland, Claire Daguin-Thiébaut. Genetics and taxonomy of Chilean smoothshelled mussels, Mytilus spp. (Bivalvia: Mytilidae). Comptes Rendus Biologies, 2012, 335 (1), pp.5161. 10.1016/j.crvi.2011.10.002 . ird-00695510v2

\section{HAL Id: ird-00695510 \\ https://hal.ird.fr/ird-00695510v2}

Submitted on 14 Jul 2012

HAL is a multi-disciplinary open access archive for the deposit and dissemination of scientific research documents, whether they are published or not. The documents may come from teaching and research institutions in France or abroad, or from public or private research centers.
L'archive ouverte pluridisciplinaire HAL, est destinée au dépôt et à la diffusion de documents scientifiques de niveau recherche, publiés ou non, émanant des établissements d'enseignement et de recherche français ou étrangers, des laboratoires publics ou privés. 
To be cited as:

Borsa P, Rolland V, Daguin C. 2012. - Genetics and taxonomy of Chilean smooth-shelled mussels, Mytilus spp.

(Bivalvia: Mytilidae). Comptes Rendus Biologies 335, 51-61.

Taxonomy / Taxinomie

Genetics and taxonomy of Chilean smooth-shelled mussels, Mytilus spp. (Bivalvia: Mytilidae)

Génétique et taxinomie des moules à coquille lisse du Chili, Mytilus spp. (Bivalvia: Mytilidae)

Philippe Borsa ${ }^{\mathrm{a},}$, , Vincent Rolland ${ }^{\mathrm{b}}$, Claire Daguin-Thiébautc

a Institut de recherche pour le développement (IRD), UR 227 « Biocomplexité des écosystèmes récifaux », Montpellier, France

b Aptiv Solutions, Clinical Database Programming, Allschwil, Switzerland

${ }^{c}$ Centre national de la recherche scientifique (CNRS) - Université Pierre et Marie Curie, UMR 7144, « Adaptation et diversité en milieu marin », Station biologique de Roscoff, France

* Author for correspondence: IRD-UMR 227, Centre IRD de Montpellier-PS2, 911 avenue Agropolis, 34032 Montpellier cedex, France ; e-mail: philippe.borsa@ird.fr 


\section{A B S T R A C T}

It has been previously established that native smooth-shelled mussels in southern South America possess close evolutionary affinities with Northern-Hemisphere Mytilus edulis L. 1758 [McDonald et al., Mar. Biol. 111 (1991) 323-333]. This result has since been challenged by authors claiming that Chilean mussels should be considered a local subspecies of M. galloprovincialis Lmk. 1819. Moreover, morphological, physiological, ecotoxicological and molecular genetic studies on Chilean smooth-shelled mussels still frequently refer to 'M. chilensis' Hupé 1854, even though the previous discovery of alien M. galloprovincialis and considerable heterogeneity in shell morphology among samples collected along the Chilean shores raise concern that different Mytilus spp. species might have been included under ' $M$. chilensis'. Here we reviewed the molecular and morphological data available on smooth-shelled mussels from Chile in an attempt to clarify both their genetic composition and their taxonomic status. Using multivariate analysis on sample $\mathrm{x}$ allozyme-frequency matrices, we confirmed the widespread occurrence of the SouthernHemisphere form of $M$. edulis along the shores from the North Patagonia region of Chile to the southern tip of the South American continent. The populations sampled in southern central Chile showed some evidence of slight introgression from Southern-Hemisphere M. galloprovincialis. Morphological characterization of a sample from Dichato in southern central Chile was consistent with its previous genetic identification as Mediterranean M. galloprovincialis. The occurrence of Southern-Hemisphere $M$. galloprovincialis in Punta Arenas at the southern tip of the South American continent was also reported. Southern-Hemisphere M. edulis, including native Chilean smooth-shelled Mytilus, should be assigned subspecific rank and named M. edulis platensis d'Orbigny 1846.

Keywords:

Molecular genotyping - Morphometrics - Invasive species - Mytilus edulis platensis - Mytilus galloprovincialis

\section{R É S U M É}

Il a été établi antérieurement que les moules à coquille lisse natives d'Amérique du Sud ont des affinités évolutives étroites avec Mytilus edulis L. 1758 de l'hémisphère Nord [McDonald et al., Mar. Biol. 111 (1991) 323-333]. Ce résultat a depuis été contesté, certains auteurs proposant que les moules chiliennes soient considérées comme une sous-espèce endémique de M. galloprovincialis Lmk. 1819. De plus, des études morphologiques, physiologiques, écotoxicologiques et de génétique moléculaire sur les moules à coquille lisse chiliennes se réfèrent régulièrement au nom d'espèce ' $M$. chilensis' Hupé 1854, bien que la découverte de M. galloprovincialis introduites, ainsi que la forte variabilité morphologique observée entre échantillons collectés le long des côtes chiliennes, suggèrent qu'un mélange d'espèces différentes soient ainsi désignées sous le terme ' $M$. chilensis'. Nous avons ici réalisé une synthèse des données morphologiques et génétiques disponibles chez les moules chiliennes afin de clarifier leur composition génétique et leur statut taxinomique. A l'aide d'analyses multivariées de matrices de fréquences allozymiques par échantillon, nous confirmons la présence de la forme australe de $M$. edulis le long des côtes chiliennes, de la partie centrale méridionale du Chili jusqu'à la pointe sud de l'Amérique du Sud. Les populations échantillonnées dans la partie centrale méridionale du Chili montrent des traces d'introgression par la forme australe de $M$.

galloprovincialis. Par ailleurs, la caractérisation morphologique d'un échantillon de Dichato (sud de la partie centrale du Chili) est en accord avec son identification moléculaire comme la forme méditerranéenne de M. galloprovincialis. La présence de la forme australe de M. galloprovincialis à Punta Arenas à l'extrémité sud du continent sud-américain est rapportée ici pour la première fois. La forme australe de $M$. edulis, qui inclut les moules à coquille lisse natives des côtes chiliennes, mérite le rang de sous-espèce et doit être désignée sous le nom M. edulis platensis d'Orbigny 1846.

Mots-clés :

Génotypage moléculaire - Morphométrie - Espèce envahissante - Mytilus edulis platensis - Mytilus galloprovincialis 


\section{Introduction}

Three species of smooth-shelled mussels, Mytilus edulis L. 1758 [1], M. galloprovincialis Lmk. 1819 [2] and M. trossulus Gould 1850 [3] have been re-defined on the basis of allozyme-genotype and concurrent morphological variation worldwide [4-6]. Although hybridization occurs in virtually every known case where two of the species occur sympatrically, evidence of restriction to gene flow despite broadcast spawning and pelagic larval transport confirms the biological status of the three species [6]. M. edulis and M. galloprovincialis are present in the temperate and cold regions of both Hemispheres, while M. trossulus is confined to the boreal and sub-boreal regions [5]. Southern-Hemisphere M. galloprovincialis are allozymically and morphologically distinct from their Northern-Hemisphere counterparts, less so M. edulis [5]. All smooth-shelled mussels from Chile examined by J.H. McDonald and co-authors [5] were closely related to those from Argentina, the Falkland Islands and the Kerguelen Islands, and all were clustered with Northern-Hemisphere M. edulis by both their allozymic composition and their shell morphology. This result has since been challenged, with authors claiming that Chilean mussels should be considered a local subspecies of M. galloprovincialis [7]. Independently, a number of authors, e.g. [8-14], have persisted in employing the species name ' $M$. chilensis' for smooth-shelled mussels sampled in Chile, ignoring previous work [5, 6] and instead following Hupé [15]. Hupé [15] mentioned the presence of $M$. chilensis "en la costa, en Valparaiso, etc." and regognized that M. chilensis "tiene enteramente el aspecto del Mytilus edulis de las mares de Europa" except that "su forma es mas aplastada". Given the morphological variation encountered within Northern-Hemisphere M. edulis [5], it remains to be proven that the reportedly flatter shell of Hupé's $M$. chilensis constitutes a character strong enough to distinguish it from $M$. edulis and assign it specific rank.

Evidence of invasion by alien Northern-Hemisphere M. galloprovincialis has been reported from localities in both the Northern and Southern Hemispheres, including the northwestern and the northeastern shores of the Pacific Ocean, southern Africa, southeastern Australia, New Zealand, and Chile ([5, 16-19] and references therein). Since Northern-Hemisphere M. galloprovincialis occurs in southern central Chile [16], presumably as the result of intentional introduction for aquaculture purposes [20], there is uncertainty as to the actual genetic composition of smooth-shelled mussels samples collected along the Chilean shores for a number of physiological, ecotoxicological, and morphological and even molecular genetic studies [8-14] undertaken since [5]. Because physiological response may vary considerably across Mytilus species [5] it is mandatory to ascertain the taxonomic status of the Chilean Mytilus material used prior to physiological analysis. Also, considerable morphological differences have been reported among samples of Chilean Mytilus spp. [11, 14], to an extent that suggests that different species may have been present, even though the authors assumed an effect solely of environmental factors.

Here we review the genetic and morphometric data published within the last two decades on smoothshelled mussels from Chile, to assess the taxonomic status of populations and eventually detect more locations along the coasts of central and southern Chile where alien M. galloprovincialis may have settled. We advocate the systematic use of a genetic assay to identify smooth-shelled Mytilus material from Chile prior to their ecological, physiological or molecular study, or to any related biomonitoring survey.

\section{Materials and Methods}

The list of smooth-shelled Mytilus samples considered in this review is presented in Table 1 and the sample locations have been reported on a map (Fig. 1). This list tentatively includes all samples from the Chilean coasts that have been genotyped at nuclear and mitochondrial markers and reported in the literature. Table 1 also includes a sample from Maullin (southern central Chile) whose genotyping at 
nuclear-DNA markers mac-1 and Glu-5' is presented here for the first time. Table 1 also presents reference samples of Northern- and Southern-Hemisphere M. edulis and M. galloprovincialis genotyped at the same marker loci.

C. Carcamo and co-authors [7] have analyzed 4 samples from the Chilean coasts, together with reference samples of Northern-Hemisphere M. edulis and M. galloprovincialis, at 23 polymorphic allozyme loci. Eight of these marker loci were common with the previously published worldwide dataset of McDonald and coauthors [5]. Homologies between electromorphs from different studies [5, 7, 23, 24, 26] were inferred as detailed in the legend to Appendix 1.

J.E. Toro and coauthors [10] have analyzed 8 samples from the Chilean coast using 7 allozyme loci. Four samples ('Ancud', 'Yaldad' 'Valdivia' and 'Pta. Arenas') were from the same locations as previous allozyme surveys [5, 7], potentially allowing cross-comparisons at two loci scored in common (Gpi, Pgm). Three other loci scored by [10] (GSR, ICD, ME) had not been scored by [5], and we were unable to establish correspondence between either of the remaining loci, $L A P$ or PEP, scored by [10] and any of the Aap, Ap or Lap loci of [5] or [7]. Correspondence between electromorphs was easily established at locus $G p i$, where electromorphs $A$ and $(B+C)$ of [10] were found to be homologous to, respectively, compound electromorphs $\leq 96$ and $\geq 98$ of [5] (Appendix 2). Locus-Pgm electromorphs $A, B$ and $(C+D)$ of [10] were found to be homologous to, respectively, electromorphs $<93,100$ and $\geq 106$ [5] (Appendix 2). Locus Gpi shows substantial electromorph-frequency differences between Southern-Hemisphere M. edulis and $M$. galloprovincialis ([5]; Appendix 1) and therefore Gpi is potentially helpful to assess the occurrence of alien $M$. galloprovincialis in Chile. We noted that allelic frequencies at locus Pgm in sample 'Pta. Arenas' of [10] were not consistent with those reported earlier [5].

The sample from Maullin (Tables 1, 2) was analyzed for polymorphism at nuclear-DNA loci mac-1 and Glu-5' and compared to other samples previously analyzed using these two markers [16, 22, 29, 32] (Appendix 3). The protocols for DNA extraction, PCR amplification and electrophoresis and staining of PCR products have been detailed previously [22]

Correspondence analysis (CA) [35] was performed to visualize samples characterized by their electromorph / allelomorph frequencies, by reducing the multidimensional allelic frequency space to a bidimensional space. Two CAs were run on allozyme-frequency data, the first one on the matrix of samples x allele-frequencies derived from Appendix 1 ('Matrix A': 15 samples x 8 allozyme loci), and the second one on a matrix comprising all samples of Appendix 1 together with the samples of [10], all characterized by their electromorph frequencies at loci Gpi and Pgm (Appendix 2) ('Matrix B': 22 samples x 2 allozyme loci). A third CA run was made on the nuclear-DNA dataset presented in Appendix 3. Hierarchical clustering analysis [36] was used to delineate clusters of samples; for this, pairwise distances between samples were Euclidean distances in the space defined by the first five axes of the CA.

Principal component analysis (PCA) was performed on the shell measurements of the samples listed in Table 2. The left shell of each individual was characterized by 10 measurements according to [5]: length of anterior adductor muscle scar (aam), length of hinge plate $(h p)$, shell height ( $h t)$, distance between umbo and posterior end of the ligament (lig), length of posterior adductor muscle scar ( $p a d$ ), distance between pallial line and ventral shell margin midway along shell ( $p a l)$, distance between umbo and posterior end of anterior retractor scar (ular), width of anterior retractor muscle scar (war), shell width (wid), and width of posterior retractor muscle scar $(w p r)$. Measurements were made to the nearest 0.1 millimeter using a digital caliper (Mitutoyo, Andover, UK) (all measurements except aam and war) or to the nearest $0.01 \mathrm{~mm}$ using an ocular micrometer fitted to a stereo microscope (Wild Heerbrugg, Aarau, Switzerland) equipped with a camera lucida (aam and war). To standardize the measurements for size, each was $\log _{10}$-transformed and divided by the $\log _{10}$-transformed shell length. PCA was run using VISTA [37]. Reference NorthernHemisphere M. edulis ( $F, G$, Northern-Hemisphere M. galloprovincialis $(S)$ and Southern-Hemisphere $M$. 
galloprovincialis $(C)$ shells were represented by average values for all 10 measurements in, respectively, samples FLØ (Flødevigen, Skagerrak; N=53), GIL (Gilleleje, northern Denmark; N=35), SET (Sète, southern France; $N=55$ ), and $C B L$ (Cloudy Bay Lagoon, Tasmania; $N=96$ ). All shells, which have been deposited at Laboratoire de biologie des invertébrés marins et malacologie, Museum national d'histoire naturelle, Paris under collection numbers MNHN-IM-2008-73 to 75, ranged in size from $20.2 \mathrm{~mm}$ to 69.2 $\mathrm{mm}$.

\section{Results}

The first axis of the CA run on Matrix A opposed reference M. galloprovincialis, to reference M. edulis samples from the Northern Hemisphere (Fig. 2A), explaining about 3/5 of the total inertia borne by the dataset. The second axis, which explained approximately an additional fifth of the total inertia, differentiated Southern-Hemisphere samples from Northern-Hemisphere M. edulis. These SouthernHemisphere samples formed a distinct, nearly continuous cluster elongated along Axis 1. The SouthernHemisphere samples genetically closest to reference Northern-Hemisphere M. edulis were samples 43 and 44 from the South Atlantic [5]. They clustered with the samples from Punta Arenas and the Kerguelen Islands (42 and 45, respectively). The samples from southern central Chile (40, 41, PAN, PPM, PQE, $P V A$ ) tended to show slight affinity towards the reference M. galloprovincialis pole (Fig. 2A) as already apparent from electromorph frequencies (Appendix 1) where Southern-Hemisphere M. galloprovincialis-like alleles at locus Est were present at higher frequency in all southern central Chile samples than in sample 42 from Punta Arenas [5]. However, there was no evidence of the presence of alien M. galloprovincialis in the Chilean Mytilus samples in the Matrix-A dataset (Fig. 2A).

All additional samples from Chile analyzed by [10] but one clustered with the other Chilean samples, together with the Southern-Hemisphere M. edulis samples from the South Atlantic and from the Kerguelen Islands (Fig. 2B). Unlike the Punta Arenas sample of [5], sample 'Pta. Arenas' of [10] clustered with the reference sample of Southern-Hemisphere M. galloprovincialis (Fig. 2B).

The nuclear-DNA dataset presented here included two smooth-shelled Mytilus spp. samples from Chile. One sample, from Dichato (CHL), was previously identified as Mediterranean M. galloprovincialis [16]; the other one, from Maullin $(M A U)$, clustered with reference Southern-Hemisphere M. edulis (Fig. 3).

Sharp morphological differences were evident between the shells of the two mussel samples from southern central Chile analyzed here (CHL and $M A U$; Table 2) (Fig. 4). Individuals of the $M A U$ sample clustered with the Southern-Hemisphere M. edulis from Kerguelen whereas those from sample CHL formed a distinct cluster at the center of which the reference sample of Northern-Hemisphere $M$. galloprovincialis was positioned.

\section{Discussion}

Evidence of alien Mediterranean M. galloprovincialis in Chile so far comes from a single sample, from Dichato (southern central Chile), previously characterized at nuclear-DNA loci mac-1 and Glu-5' [16] and at the mitochondrial locus $C O I$ [21], and here also shown to be morphologically identical to reference Northern-Hemisphere M. galloprovincialis. Additional evidence of Northern-Hemisphere M. galloprovincialis mitotypes has recently been reported in samples from Concepcion and Colchogue, two localities in southern central Chile [18]. All the other smooth-shelled Mytilus samples from Chile reviewed in the present study, but one, were identified as Southern-Hemisphere M. edulis since they clustered with 
reference samples from the South Atlantic and from the Kerguelen Islands, both genetically and by their shell morphology ([5, 21], present study). The exception is a sample from Punta Arenas [10] at the southern tip of South America, which was here identified as Southern-Hemisphere M. galloprovincialis on the basis of allozyme frequencies at loci Pgm and Gpi. This sample has also been analyzed morphologically [11] and found to be significantly different from all the other samples from Chile (distribution of samples along principal component 1 [11]: Dixon's test for detecting outliers [39]; $Q=0.545 ; N=8 ; P<0.05$ ). The mussels in this sample $[10,11]$ were characterized by a concave and slightly pointed umbo [11], consistent with their allozyme identification as Southern-Hemisphere M. galloprovincialis (present work).

How can we explain the occurrence of Southern-Hemisphere M. galloprovincialis at a location and in a region where only Southern-Hemisphere M. edulis had been previously reported [5]? Southern-Hemisphere M. galloprovincialis are native from temperate Australia, Tasmania, and New Zealand [5, 16, 18, 19, 21] while Southern-Hemisphere M. edulis are native from southern South America, the Falkland Islands and the Kerguelen Islands [5, 21], and possibly other islands in the Southern Ocean. The distribution areas of the two species are separated by a stretch of ocean of over $105^{\circ}$ longitude, from New Zealand to Chile. An hypothesis is that the introduction of Southern-Hemisphere M. galloprovincialis to Punta Arenas is recent and has been caused by maritime traffic, since Punta Arenas is a port of call for global shipping lines that link New Zealand to South America (http://www.timetableimages.com/maritime/). The alternative hypothesis, that both species naturally co-occur in the Punta Arenas area, but that Southern-Hemisphere M. galloprovincialis had previously escaped detection there and all along the cold-temperate shores of South America is, in our view, much less likely. To test the hypothesis that the Southern-Hemisphere $M$. galloprovincialis sample of $[10,11]$ consists of alien mussels would require genotyping them at marker loci able to distinguish different sub-populations within that population, e. g. the COI marker [21].

Valladares and co-authors [14] have similarly reported strong morphological differences between cultivated mussels from southern central Chile and wild mussels from the same area and from the Magellanic region of southern Chile. The authors ascribed these differences to differences in ecological pressure on cultivated vs. wild populations. However, no genetic assay was performed, that would help confirm that the cultivated populations analyzed by [14] were native mussels as assumed by the authors, and not alien M. galloprovincialis, despite earlier reports mentioning alien M. galloprovincialis in southern central Chile [16, 20, 21] and its introduction to mussel farms [20]. Cultivated Chilean mussels differed from wild mussels by umbo shape and orientation, and ligament length [14]. These features have proven useful for distinguishing M. galloprovincialis from M. edulis [5, 40]. Therefore, genetic assays are necessary to ascertain that the cultivated smooth-shelled Mytilus samples from southern central Chile analyzed by [14] were not in fact $M$. galloprovincialis.

In conclusion, the present study confirmed the presence of Mediterranean M. galloprovincialis in southern central Chile, and uncovered the occurrence of Southern-Hemisphere M. galloprovincialis in Punta Arenas. The term ' $M$. chilensis' employed by different authors for smooth-shelled mussels sampled in Chile actually concerns Southern-Hemisphere M. edulis and so-far unreported Southern-Hemisphere $M$. galloprovincialis, and potentially concerns alien Northern-Hemisphere M. galloprovincialis.

Since morphological characterization of mussel samples has apparently been insufficient for some authors to see mixtures of species in their samples [11], we advocate the systematic use of a genetic assay to identify smooth-shelled Mytilus material from Chile prior to their ecological, physiological or molecular study, or to any related biomonitoring survey. The single marker of choice for identifying smooth-shelled Mytilus spp. to species is mac-1 ([16, 22]; present study). In particular, mac-1 allows the distinction of Southern-Hemisphere M. edulis and M. galloprovincialis from their Northern-Hemisphere counterparts [22]. Alternatively, a two-locus diagnostic has been proposed recently [18]. Several studies have employed ITS and Glu-5' (or Me15/16, which is part of the same gene [34]) to identify Chilean mussels [8,9] but ITS 
does not separate Southern-Hemisphere M. edulis from either Northern-Hemisphere M. edulis or Northern-Hemisphere M. galloprovincialis [9, 41] and Glu-5' (or Me15/10) does not separate SouthernHemisphere M. edulis from M. galloprovincialis [18, 22, 34].

Southern-Hemisphere M. edulis are distinct from Northern-Hemisphere M. edulis at a proportion of nuclear loci ([5, 22], present work) and at the mitochondrial locus [21], to an extent that warrants their recognition as a separate, geographically isolated entity. Therefore, it is sensible to assume sub-specific rank for them. The valid subspecific name for Southern-Hemisphere M. edulis is M. edulis platensis d'Orbigny 1846 [42] by the principle of priority [43]. Under the same rationale, Southern-Hemisphere $M$. galloprovincialis should be assigned the subspecific name M. galloprovincialis planulatus Lmk 1819 [2]. Epithet chilensis being a junior synonym of platensis (as is desolationis Lamy 1936 [44]), it should be abandoned.

\section{Acknowledgements}

The original morphometric and molecular analyses presented in this paper were done at Station méditerranéenne de l'environnement littoral, Sète, in 1997-2000 in the course of CD's Ph.D. and VR's B.Sc. We gratefully acknowledge the support of F. Bonhomme and B. Delay. We are also grateful to J. Beesley, F. Bonhomme, W. Borgeson, P. Boudry, Y. Cherel, P. Fréon, A. Leitao, C. Lemaire, J. Panfili, C. Perrin, and M. Raymond for collecting mussels from, respectively, Nedlands, Chioggia, Bodega Bay, South Korea, Kerguelen, Bloubergstrand, Setubal, Grand Fort Philippe, Flødevigen, Dunedin, and Gilleleje. The mussel sample from Dichato was provided by C. Riquelme and D. Moraga, and that from Maullin was provided by S. Faugeron and S. Morales. We thank D.J. Colgan for editorial corrections on a former version of the manuscript and for encouragements, him and M. Valero for help with the literature, and P. Bouchet and his assistants for curating the mussel specimens deposited by us at MNHN, Paris. J.H. McDonald kindly provided the details in his possession on the sampling sites and dates of reference $M$. edulis platensis samples. Two anonymous reviewers offered helpful suggestions.

\section{References}

[1] Linnaeus, C., Systema naturae per regna tria naturae, secundum classes, ordines, species, cum characteribus, differentiis, synonymis, locis, Tomus I, editio decima, reformata, Laurentii Salvii, Stockholm, 1758, 824 pp.

[2] de Lamarck, J.B., Histoire naturelle des animaux sans vertèbres présentant les caractères généraux et particuliers de ces animaux, leur distribution, leurs classes, leurs familles, leurs genres, et la citation des principales espèces qui s'y rapportent, Tome sixième, Librairie Verdière, Paris, 1819, 232 pp.

[3] Gould, A.A., Shells from the United States exploring expedition, Proc. Boston Soc. Nat. Hist. 3 (1850) 343-348.

[4] McDonald, J.H., R.K. Koehn, The mussels Mytilus galloprovincialis and M. trossulus on the Pacific coast of North America, Mar. Biol. 99 (1988) 111-118.

[5] McDonald, J.H., R. Seed, R.K. Koehn, Allozymes and morphometric characters of three species of Mytilus in the northern and southern hemispheres, Mar. Biol. 111 (1991) 323-333.

[6] Koehn, R.K., The genetics and taxonomy of species in the genus Mytilus, Aquaculture 94 (1991) 125-145.

[7] Carcamo, C., A.S. Comesaña, F.M. Winkler, A. Sanjuan, Allozyme identification of mussels (Bivalvia: Mytilus) on the Pacific coast of South America, J. Shellfish Res. 24 (2005) 1101-1115.

[8] Toro, J.E., PCR-based nuclear and mtDNA markers and shell morphology as an approach to study the taxonomic status of the Chilean blue mussel, Mytilus chilensis (Bivalvia), Aquat. Living Resour. 11 (1998) 347-353.

[9] Toro, J.E., J.A. Ojeda, A.M. Vergara, G.C. Castro, A.C. Alcapán, Molecular characterization of the Chilean blue mussel (Mytilus chilensis Hupe 1854) demonstrates evidence for the occurrence of Mytilus galloprovincialis in southern Chile, J. Shellfish Res. 24 (2005) 1117-1121.

[10] Toro, J.E., G.C. Castro, J.A. Ojeda, A.M. Vergara, Allozymic variation and differentiation in the Chilean blue mussel, Mytilus chilensis, along its natural distribution, Genet. Mol. Biol. 29 (2006) 174-179. 
[11] Krapivka, S., J.E Toro, A.C. Alcapán, M. Astorga, P. Presa, M. Pérez, R. Guiñez, Shell-shape variation along the latitudinal range of the Chilean blue mussel Mytilus chilensis (Hupe 1854), Aquaculture Res. 38 (2007) 1770-1777.

[12] Hervé-Fernández, P., F. Houlbreque, F. Boisson, S. Mulsow, J.L. Teyssie, F. Oberhaensli, S. Azemard, R. Jeffree, Cadmium bioaccumulation and retention kinetics in the Chilean blue mussel Mytilus chilensis: seawater and food exposure pathways, Aquat. Toxicol. 99(2010) 448-456.

[13] Navarro, J.M., A.M. Contreras, An integrative response by Mytilus cbilensis to the toxic dinoflagellate Alexandrium catenella, Mar. Biol. 157 (2010) 1967-1974.

[14] Valladares, A., G. Manríquez, B.A. Suárez-Isla, Shell shape variation in populations of Mytilus chilensis (Hupe 1854) from southern Chile: a geometric morphometric approach, Mar. Biol. 157 (2010) 2731-2738.

[15] Hupé, H., Moluscos de Chile, in: Gay, C. (ed), Historia fisica y politica de Chile, Zoologia, Vol. 8, C. Gay, Paris, 1854, pp. 1407.

[16] Daguin, C., P. Borsa, Genetic relationships of Mytilus galloprovincialis Lmk. populations worldwide: evidence from nuclearDNA markers, Geol. Soc. Lond. Spec. Publ. 177 (2000) 389-397.

[17] Wonham, M.J., Mini-review: distribution of the Mediterranean mussel Mytilus galloprovincialis (Bivalvia : Mytilidae) and hybrids in the Northeast Pacific, J. Shellfish Res. 23 (2004) 535-543.

[18] Westfall, K.M., J.P.A. Gardner, Genetic diversity of Southern hemisphere blue mussels (Bivalvia: Mytilidae) and the identification of non-indigenous taxa, Biol. J. Linn. Soc. 101 (2010) 898-909.

[19] Colgan, D.J., P. Middelfart, Mytilus mitochondrial DNA haplotypes in southeastern Australia, Aquat. Biol. 12 (2011) 49-55.

[20] Castilla, J.C., M. Uribe, N. Bahamonde, M. Clarke, R. Desqueyroux-Faúndez, I. Kong, H. Moyano, N. Rozbaczylo, B. Santelices, C. Valdovinos, P. Zavala, Down under the Southeastern Pacific: marine non-indigenous species in Chile, Biol. Invasions 7 (2005) 213-232.

[21] Gérard, K., N. Bierne, P. Borsa, A. Chenuil, J.-P. Féral, Pleistocene separation of mitochondrial lineages of Mytilus spp. mussels from Northern and Southern Hemispheres and strong genetic differentiation among southern populations, Mol. Phylogenet. Evol. 49 (2008) 84-91.

[22] Borsa, P., C. Daguin, N. Bierne, Genomic reticulation indicates mixed ancestry in Southern-Hemisphere Mytilus spp. mussels, Biol. J. Linn. Soc. 92 (2007) 747-754.

[23] McDonald, J.H., R.K. Koehn, E.S. Balakirev, G.P. Manchenko, A.I. Pudovkin, S.O. Sergiyevsky, K.V. Krutovsky, Видовая принадпежность “съедобной мидии”, обитающей в приазиатской части тихого океана, Biol. Morya (1990) 13-22

[24] Varvio, S.-L., R.K. Koehn, R. Väinölä, Evolutionary genetics of the Mytilus edulis complex in the North Atlantic region, Mar. Biol. 98 (1988) 51-60.

[25] Riginos, C., M.J. Hickerson, , C.M. Henzler, C.W. Cunningham, Differential patterns of male and female mtDNA exchange across the Atlantic Ocean in the blue mussel, Mytilus edulis, Evolution 58 (2004) 2438-2451.

[26] Quesada, H., C. Zapata, G.Alvarez, A multilocus allozyme discontinuity in the mussel Mytilus galloprovincialis: the interaction of ecological and life-history factors, Mar. Ecol. Prog. Ser. 116 (1995) 99-115.

[27] Rawson, P.D., T.J. Hilbish, Asymmetric introgression of mitochondrial DNA among European populations of blue mussels (Mytilus spp.), Evolution 52 (1998) 100-108.

[28] Ryan, W.B.F., S.M. Carbotte, J.O. Coplan, S. O’Hara, A. Melkonian, R. Arko, R.A. Weissel, V. Ferrini, A. Goodwillie, F. Nitsche, J. Bonczkowski, R. Zemsky, Global multi-resolution topography synthesis, Geochem. Geophys. Geosyst. 10 (2009) Q03014.

[29] Borsa, P., C. Daguin, S. Ramos Caetano, F. Bonhomme, Nuclear-DNA evidence that northeastern Atlantic Mytilus trossulus carry M. edulis genes, J. Mollus. Stud. 65 (1999) 524-527.

[30] Coustau, C, F. Renaud, B. Delay, Genetic characterization of the hybridization between Mytilus edulis and M. galloprovincialis on the Atlantic coast of France, Mar. Biol. 111 (1991) 87-93.

[31] Väinölä, R., M.M. Hvilsom, Genetic divergence and a hybrid zone between Baltic and North Sea Mytilus populations. Biol. J. Linn. Soc. 43 (1991) 127-148.

[32] Daguin, C., F. Bonhomme, P. Borsa, The zone of sympatry and hybridization of Mytilus edulis and M. galloprovincialis, as described by intron-length polymorphism at locus mac-1, Heredity 86 (2001) 342-354.

[33] Daguin, C., P. Borsa, Genetic characterisation of Mytilus galloprovincialis Lmk. in North West Africa using nuclear DNA markers, J. Exp. Mar. Biol. Ecol. 235 (1999) 55-65.

[34] Rawson, P.D., K.L. Joyner, K. Meetze, T.J. Hilbish, Evidence for intragenic recombination within a novel genetic marker that distinguishes mussels in the Mytilus edulis species complex, Heredity 77 (1996) 599-607.

[35] Benzécri, J.-P., L’analyse des données, 2, L’analyse des correspondances, Dunod, Paris, 1982.

[36] Lê, S., J. Josse, F. Husson, FACTOMineR: an R package for multivariate analysis, J. Stat. Software 25 (2008) 1.

[37] Young, F.W., P.M. Valero-Mora, M. Friendly, Visual statistics: seeing data with dynamic interactive graphics, John Wiley and Sons, Hoboken NJ, 2006.

[38] Ihaka, R., R. Gentleman, R: a language for data analysis and graphics, J. Comput. Graph. Stat. 5 (1996) 299-314. 
[39] Sokal, R.R., F.J. Rohlf, Biometry: the principles and practice of statistic in biological research, W.H. Freeman and Co., San Francisco CA, 1969, 776 pp.

[40] Lubet, P., G. Prunus, M. Masson, D. Bucaille, Recherches expérimentales sur l'hybridation de Mytilus edulis L. et M. galloprovincialis Lmk (mollusques lamellibranches), Bull. Soc. Zool. Fr. 104 (1984) 87-98.

[41] Heath, D.D., P.D. Rawson, T.J. Hilbish, PCR-based nuclear markers identify alien blue mussel (Mytilus spp.) genotypes on the west coast of Canada. Can. J.f. Fish. Aquat. Sci. 52 (1995) 2621-2627.

[42] d'Orbigny, A., Voyage dans l'Amérique méridionale (le Brésil, la république orientale de l’Uruguay, la république Argentine, la Patagonie, la république du Chili, la république de Bolivia, la république du Pérou), exécuté pendant les années 1826, 1827, 1828, 1829, 1830, 1831, 1832 et 1833, Bertrand: Paris, Vol. 5, Mollusques (1836) 49-184, Atlas, 1846, 20 pls.

[43] International Commission on Zoological Nomenclature, International code of zoological nomenclature, 4th edn, International Trust for Zoological Nomenclature, London, 1999, 306 pp.

[44] Lamy, E., Révision des Mytilidae vivants du Museum national d'histoire naturelle de Paris, J. Conch. Paris 80 (1936) 66-102, 107-198. 
Table 1

Smooth-shelled Mytilus spp. samples examined in the present review, including samples from the Chilean coastline and reference samples from Northern- and Southern-Hemisphere M. edulis and M. galloprovincialis.

\begin{tabular}{|c|c|c|c|c|c|c|}
\hline \multicolumn{4}{|l|}{ Sample } & \multirow[t]{2}{*}{$N$} & \multirow[t]{2}{*}{ Marker loci } & \multirow[t]{2}{*}{ Reference } \\
\hline Location & Coordinates & Abbreviation & Date & & & \\
\hline \multicolumn{7}{|l|}{ Chilean Mytilus spp. } \\
\hline Valdivia & $39^{\circ} 51^{\prime} \mathrm{S} 73^{\circ} 27^{\prime} \mathrm{W}$ & $P V A$ & Feb. 1997-May 1998 & 55- 61 & allozymes & [7] \\
\hline Puerto Montt & $41^{\circ} 33^{\prime} \mathrm{S} 72^{\circ} 48^{\prime} \mathrm{W}$ & $P P M$ & Feb. 1997-May 1998 & $68-71$ & allozymes & [7] \\
\hline Ancud & $41^{\circ} 51^{\circ} \mathrm{S} 73^{\circ} 50^{\circ} \mathrm{W}$ & $P A N$ & Feb. 1997-May 1998 & $31-41$ & allozymes & [7] \\
\hline Quellón & $43^{\circ} 08^{\prime} \mathrm{S} 73^{\circ} 39^{\prime} \mathrm{W}$ & $P Q E$ & Feb. 1997-May 1998 & 37- 72 & allozymes & [7] \\
\hline Arauco & $37^{\circ} 14^{\prime} \mathrm{S} 73^{\circ} 19^{\prime} \mathrm{W}$ & Arauco & - & $109-112$ & allozymes & {$[10]$} \\
\hline Queule & $\sim 39^{\circ} \mathrm{S} \sim 73^{\circ} \mathrm{W}$ & Queule & - & $80-108$ & allozymes & {$[10]$} \\
\hline Valdivia & $\sim 40^{\circ} \mathrm{S} \sim 73^{\circ} \mathrm{W}$ & Valdivia & - & $102-116$ & allozymes & {$[10]$} \\
\hline Calbuco & $\sim 41^{\circ} \mathrm{S} \sim 73^{\circ} \mathrm{W}$ & Calbuco & - & 110 & allozymes & {$[10]$} \\
\hline Ancud & $\sim 42^{\circ} \mathrm{S} \sim 74^{\circ} \mathrm{W}$ & Ancud & - & 99-110 & allozymes & {$[10]$} \\
\hline Yaldad & $\sim 43^{\circ} \mathrm{S} \sim 73^{\circ} \mathrm{W}$ & Yaldad & - & $111-128$ & allozymes & {$[10]$} \\
\hline Pto. Marin Balmaceda & $\sim 43^{\circ} \mathrm{S} \sim 73^{\circ} \mathrm{W}$ & Marin & - & 99 & allozymes & {$[10]$} \\
\hline Punta Arenas & $53^{\circ} 08^{\prime} \mathrm{S} 70^{\circ} 55^{\prime} \mathrm{W}$ & Arenas & - & $100-107$ & allozymes & {$[10]$} \\
\hline Dichato & $36^{\circ} 33^{\prime} \mathrm{S} 72^{\circ} 57^{\prime} \mathrm{W}$ & CHL & Oct. 1998 & 9- 76 & mac-1, Glu-5, COI & {$[16,21]$} \\
\hline Maullin & $41^{\circ} 37^{\prime} \mathrm{S} 73^{\circ} 36^{\prime} \mathrm{W}$ & $M A U$ & Jan. 1999 & 7- 52 & mac-1, Glu-5, COI & [21], present work \\
\hline Concepcion & $36^{\circ} 44^{\prime} \mathrm{S} 73^{\circ} 08^{\prime} \mathrm{W}$ & $\mathrm{CO}$ & 1994-2009 & 19 & Me15/16, 165 & {$[18]$} \\
\hline Colchogue & $37^{\circ} 03^{\prime} \mathrm{S} 73^{\circ} 10^{\prime} \mathrm{W}$ & $C L$ & 1994-2009 & 20 & $\mathrm{Me} 15 / 16,16 \mathrm{~S}$ & [18] \\
\hline \multicolumn{7}{|l|}{ Southern-Hemisphere M. edulis } \\
\hline Yaldad Bay, Chile & $\sim 43^{\circ} \mathrm{S} \sim 73^{\circ} \mathrm{W}$ & 40 & 1986 & 25 & allozymes & {$[5]$} \\
\hline Chiloe, Chile & $42-43^{\circ} \mathrm{S} 73-74^{\circ} \mathrm{W}$ & 41 & Jan. 1988 & 23 & allozymes & [5] \\
\hline Punta Arenas, Chile & $\sim 53^{\circ} \mathrm{S} \sim 71^{\circ} \mathrm{W}$ & 42 & Jan. 1988 & 25 & allozymes & [5] \\
\hline Mar del Plata, Argentina & $\sim 38^{\circ} \mathrm{S} \sim 57^{\circ} \mathrm{W}$ & 44 & $1985-1988$ & 25 & allozymes & [5] \\
\hline Falkland Islands a & $51-52^{\circ} \mathrm{S} 58-61^{\circ} \mathrm{W}$ & 43 & 1985-1988 & 25 & allozymes & [5] \\
\hline Kerguelen Islands & $\sim 49^{\circ} \mathrm{S} \sim 69^{\circ} \mathrm{E}$ & 45 & July 1988 & 22 & allozymes & [5] \\
\hline Kerguelen Islands & $49^{\circ} 28^{\prime} \mathrm{S} 69^{\circ} 56^{\prime} \mathrm{E}$ & KER & June 1997 & $79-83$ & mac-1, Glu-5, COI & {$[21,22]$} \\
\hline \multicolumn{7}{|c|}{ Southern-Hemisphere $M$. galloprovincialis } \\
\hline Huon River Estuary, Tasmania & $\sim 43^{\circ} \mathrm{S} \sim 147^{\circ} \mathrm{E}$ & 47 & 1985-1988 & 23 & allozymes & {$[5]$} \\
\hline Nedlands, Western Australia & $32^{\circ} 03^{\prime} \mathrm{S} 115^{\circ} 44^{\prime} \mathrm{E}$ & AUS & July 1998 & 7- 46 & mac-1, Glu-5, COI & {$[16,21]$} \\
\hline Adventure Bay, Tasmania & $43^{\circ} 21^{\prime} \mathrm{S} 147^{\circ} 22^{\prime} \mathrm{E}$ & $A D B$ & Mar. 1997 & $26-28$ & mac-1, Glu-5' & {$[22]$} \\
\hline Alonnah, Tasmania & $43^{\circ} 18^{\prime} \mathrm{S} 147^{\circ} 14^{\prime} \mathrm{E}$ & ALO & Mar. 1997 & 25- 59 & mac-1, Glu-5 & {$[22]$} \\
\hline Cloudy Bay Lagoon, Tasmania & $43^{\circ} 25^{\prime} \mathrm{S} 147^{\circ} 12^{\prime} \mathrm{E}$ & $C B L$ & Feb. 1997 & 5- 32 & mac-1, Glu-5', COI & {$[21,22]$} \\
\hline Hobart, Tasmania & $42^{\circ} 53^{\prime} \mathrm{S} 147^{\circ} 20^{\prime} \mathrm{E}$ & $H O B$ & Feb. 1997 & 8- 31 & mac-1, Glu-5', COI & {$[21,22]$} \\
\hline Partridge Narrows, Tasmania & $43^{\circ} 24^{\prime} \mathrm{S} 147^{\circ} 06^{\prime} \mathrm{E}$ & $P A R$ & Mar. 1997 & $25-30$ & mac-1, Glu-5 & {$[22]$} \\
\hline Simpson's Bay, Tasmania & $43^{\circ} 17^{\prime} \mathrm{S} 147^{\circ} 20^{\prime} \mathrm{E}$ & SIM & Mar. 1997 & 3- 40 & mac-1, Glu-5', COI & {$[21,22]$} \\
\hline Dunedin, New Zealand & $45^{\circ} 55^{\prime} \mathrm{S} 170^{\circ} 28^{\prime} \mathrm{E}$ & $D U N(=N Z L)$ & June 1999 & 6- 79 & mac-1, Glu-5, COI & {$[16,21]$} \\
\hline \multicolumn{7}{|l|}{ Northern-Hemisphere M. edulis } \\
\hline Aarhus, Denmark & $56^{\circ} 10^{\prime} \mathrm{N} 10^{\circ} 14^{\prime} \mathrm{E}$ & Aapxyc & $1985-1988$ & 11 & allozymes & {$[23,24]$} \\
\hline Netherlands & - & $\mathrm{EH}$ & - & 59- 75 & allozymes & [7] \\
\hline Gilleleje, Kattegat & $56^{\circ} 07^{\prime} \mathrm{N} 12^{\circ} 18^{\prime} \mathrm{E}$ & GIL & Sep. 1996 & $16-26$ & mac-1, Glu-5, & [16] \\
\hline Flødevigen, Skagerrak & $58^{\circ} 25^{\prime} \mathrm{N} 08^{\circ} 45^{\prime} \mathrm{E}$ & FLO & Jan. 1997 & $20-47$ & mac-1, Glu-5, COI b & {$[16,21]$} \\
\hline Grand Fort Philippe, N France & $51^{\circ} 00^{\prime} \mathrm{N} 02^{\circ} 05^{\prime} \mathrm{E}$ & GFP & June 1997 & 42 & mac-1, Glu-5' & {$[16]$} \\
\hline \multicolumn{7}{|c|}{ Northern-Hemisphere $M$. galloprovincialis } \\
\hline Vigo, Spain & $\sim 42^{\circ} \mathrm{N} \sim 09^{\circ} \mathrm{W}$ & $G V$ & - & 35- 73 & allozymes & [7] \\
\hline Palavas, Western Mediterranean & $43^{\circ} 31^{\prime} \mathrm{N} 03^{\circ} 56^{\prime} \mathrm{E}$ & Palavas & 1988-1990 & $75-100$ & allozymes & [26] \\
\hline Setubal, Portugal & $38^{\circ} 29^{\prime} \mathrm{N}, 08^{\circ} 56^{\prime} \mathrm{E}$ & $S T B$ & Sep. 1997 & 19- 26 & mac-1, Glu-5' & {$[22]$} \\
\hline Sète, Western Mediterranean & $43^{\circ} 24^{\prime} \mathrm{N} 03^{\circ} 41^{\prime} \mathrm{E}$ & SET & May 1996 & $56-68$ & mac-1, Glu-5 & {$[16]$} \\
\hline Chioggia, Adriatic Sea & $45^{\circ} 13^{\prime} \mathrm{N} 12^{\circ} 18^{\prime} \mathrm{E}$ & $\mathrm{CHI}$ & June 1997 & $18-47$ & mac-1, Glu-5 & {$[22]$} \\
\hline Bloubergstrand, South Africa & $33^{\circ} 48^{\prime} \mathrm{S} 18^{\circ} 27^{\prime} \mathrm{E}$ & $S A F$ & Nov. 1998 & $62-65$ & mac-1, Glu-5 & {$[16]$} \\
\hline Southern Korean Peninsula & $\sim 35^{\circ} \mathrm{N} \sim 126^{\circ} \mathrm{E}$ & KOR & $<1999$ & 19- 30 & mac-1, Glu-5 & {$[16]$} \\
\hline Bodega Bay, California & $38^{\circ} 19^{\prime} \mathrm{N} 123^{\circ} 04^{\prime} \mathrm{W}$ & $B O D$ & Nov. 1996 & $23-34$ & mac-1, Glu-5 & {$[16]$} \\
\hline Sète, Western Mediterranean & $\sim 43^{\circ} \mathrm{N} \sim 03^{\circ} \mathrm{E}$ & $G-F r$ & $<1998$ & 17 & $16 \mathrm{~S}$ & {$[27]$} \\
\hline
\end{tabular}

a sample consisting of a mixture of individuals from Stanley Harbour $\left(51^{\circ} 42^{\prime} \mathrm{S} 57^{\circ} 49^{\prime} \mathrm{W}\right)$ and individuals from the West Falkland Island

b COI sequences originally are from sample ‘Tjärnö, Sweden’ [25] 
Table 2

Smooth-shelled Mytilus spp. Summary of genetic characteristics at nuclear-DNA loci mac-1and Glu-5' ([16, 22, 29] and unpublished data) and mitochondrial locus COI [21] of two samples from Chile (CHL, MAU) and reference samples (CBL, FLØ, GIL, KER, SET), all analysed morphometrically (Fig. 4). Allosymes: genetic characterization of samples from the same or nearby locations, previously analyzed at 7-8 allozyme loci [5, 24, 30,31]; E, G: compound alleles characteristic of $M$. edulis and M. galloprovincialis, respectively; $N_{A}$ bulk of the $N$ clade that includes all Northern-Hemisphere $M$. edulis, and a proportion of Northern-Hemisphere $M$. galloprovincialis female COI haplotypes; $N_{D}$ well-supported subclade of the $N$ clade that exclusively comprises Northern-Hemisphere M. galloprovincialis female COI haplotypes [19,21]. N: sample size; $n d$ : no data.

\begin{tabular}{|c|c|c|c|c|c|c|c|c|c|c|c|c|}
\hline \multirow[t]{3}{*}{ Sample } & \multicolumn{12}{|c|}{ Marker } \\
\hline & \multicolumn{3}{|c|}{ mac-1 } & \multicolumn{3}{|c|}{ Glu-5' } & \multicolumn{5}{|l|}{ COI } & \multirow[t]{2}{*}{ Allozymes } \\
\hline & $E$ & $G$ & $(N)$ & $E$ & $G$ & $(N)$ & $N_{A}$ & $N_{D}$ & $S_{1}$ & $S_{3}$ & $(N)$ & \\
\hline CHL & 0.04 & 0.96 & (76) & - & 1.00 & (48) & 0.22 & 0.78 & - & - & (9) & nd \\
\hline$M A U$ & 1.00 & - & (52) & - & 1.00 & (28) & - & - & 1.00 & - & (7) & $E$ \\
\hline$C B L$ & 1.00 & - & (32) & - & 1.00 & (29) & - & - & - & 1.00 & (5) & $G$ \\
\hline FLO a & 1.00 & - & (47) & 1.00 & - & (35) & 1.00 & - & - & - & $(20)$ & $E$ \\
\hline GIL & 1.00 & - & (26) & 1.00 & - & (16) & nd & nd & nd & nd & nd & $E$ \\
\hline KER & 1.00 & - & (83) & 0.35 & 0.65 & (79) & - & - & 1.00 & - & (83) & $E$ \\
\hline SET b & 0.03 & 0.97 & (68) & 0.06 & 0.94 & (39) & 0.65 & 0.35 & - & - & (17) & $G$ \\
\hline
\end{tabular}

a COI data from sample 'Tjärnö, Sweden' [25]; b female-mitochondrial composition determined from $16 S$ RFLP haplotypes of sample $G-F r[27]$ 
Fig. 1. Sampling sites for smooth-shelled Mytilus spp. A. Sampling locations for M. edulis and M. galloprovincialis in the Northern and the Southern Hemispheres. B. Map of the southern tip of South America, including all sampling sites for smooth-shelled Mytilus spp. in Chile $([5,7,10,16,18,20-24]$; present study). Full triangles $(\boldsymbol{\Delta})$ : Northern-Hemisphere M. edulis; full circles $(\bullet)$ : Northern-Hemisphere M. galloprovincialis; open triangles $(\Delta)$ : Southern-Hemisphere M. edulis; diamonds ( $)$ : Southern-Hemisphere $M$. galloprovincialis. Background topographic map from GEOMAPAPP [28] (http://www.geomapapp.org).

Fig. 2. Genetic relationships of Chilean Mytilus spp. Projection of samples from Chile together with reference samples of Northern-Hemisphere M. edulis (EH and Aapxyc), Southern-Hemisphere M. edulis (43-45), Northern-Hemisphere M. galloprovincialis (GV and Palavas), and Southern-Hemisphere M. galloprovincialis (47). Samples were characterized by their electromorph frequencies at allozyme loci and the resulting matrix was subjected to correspondence analysis [35] using the FACTOMineR package [36] under R [38]; percentages for each axis are their inertias [35]; ellipses delineate clusters of samples determined by hierarchical clustering [36] , allowing the identification to species and subspecies of the tested samples.. Full triangles $(\boldsymbol{\Delta})$ : Northern-Hemisphere M. edulis; full circles $(\bullet)$ : Northern-Hemisphere M. galloprovincialis; open triangles $(\Delta)$ : SouthernHemisphere M. edulis; diamonds ( ): Southern-Hemisphere M. galloprovincialis. A. Analysis performed on Matrix A (15 samples x 8 allozyme loci). B. Analysis performed on Matrix B (23 samples x 2 allozyme loci).

Fig. 3. Genetic relationships of Chilean Mytilus spp. Projection of samples from Chile together with reference samples of Northern-Hemisphere M. edulis (FLØ, GFP and GIL), Southern-Hemisphere M. edulis (KER), Northern-Hemisphere $M$. galloprovincialis (BOD, CHI KOR, SET and STB), and Southern-Hemisphere M. galloprovincialis (ADB, ALO, AUS, CBL, DUN, $H O B, P A R$ and $S I M)$. Samples were characterized by their allelomorph frequencies at nuclear-DNA loci mac-1 and Glu-5, (Appendix 3) and the resulting matrix was subjected to correspondence analysis [35, 36]. Ellipses delineate clusters of samples determined by hierarchical clustering [36], allowing the identification to species and subspecies of the tested samples. Full triangles $(\boldsymbol{\Lambda})$ : Northern-Hemisphere M. edulis; full circles $(\bullet)$ : Northern-Hemisphere M. galloprovincialis; open triangles $(\Delta)$ : SouthernHemisphere M. edulis; diamonds ( ): Southern-Hemisphere M. galloprovincialis.

Fig. 4. Shell morphometrics of Chilean Mytilus spp. Projection on the plane defined by axes 2 and 3 of principal component analysis (PCA) [37] of individuals sampled in Dichato, Chile (sample CHL in Table 1: full circles; N=80), Maullin, Chile (MAU: thinner triangles; $N=56$ ) and Kerguelen (KER: thicker triangles; $N=101)$; inset: correlation circle indicating the relative contribution (proportional to size of arrow) of each shell measurement; the quality of representation of a shell measurement can be visualized by the distance between its projection on the plane and the correlation circle. The left shell of each individual was characterized by 10 measurements according to [5]: length of anterior adductor muscle scar (aam), length of hinge plate ( $h p$ ), shell height (bt), distance between umbo and posterior end of the ligament (lig), length of posterior adductor muscle scar (pad), distance between pallial line and ventral shell margin midway along shell $(p a l)$, distance between umbo and posterior end of anterior retractor scar (ular), width of anterior retractor muscle scar (war), shell width (wid), and width of posterior retractor muscle scar (wpr). Reference Northern-Hemisphere M. edulis $(F, G)$, Northern-Hemisphere M. galloprovincialis (S) and Southern-Hemisphere M. galloprovincialis (C) shells were represented by average values for all 10 measurements in, respectively, samples FL (Flødevigen, Skagerrak; N=53), GIL (Gilleleje, northern Denmark; N=35), SET (Sète, southern France; N=55), and CBL (Cloudy Bay Lagoon, Tasmania; $N=96$ ) and incorporated as illustrative variables in the PCA. 
A

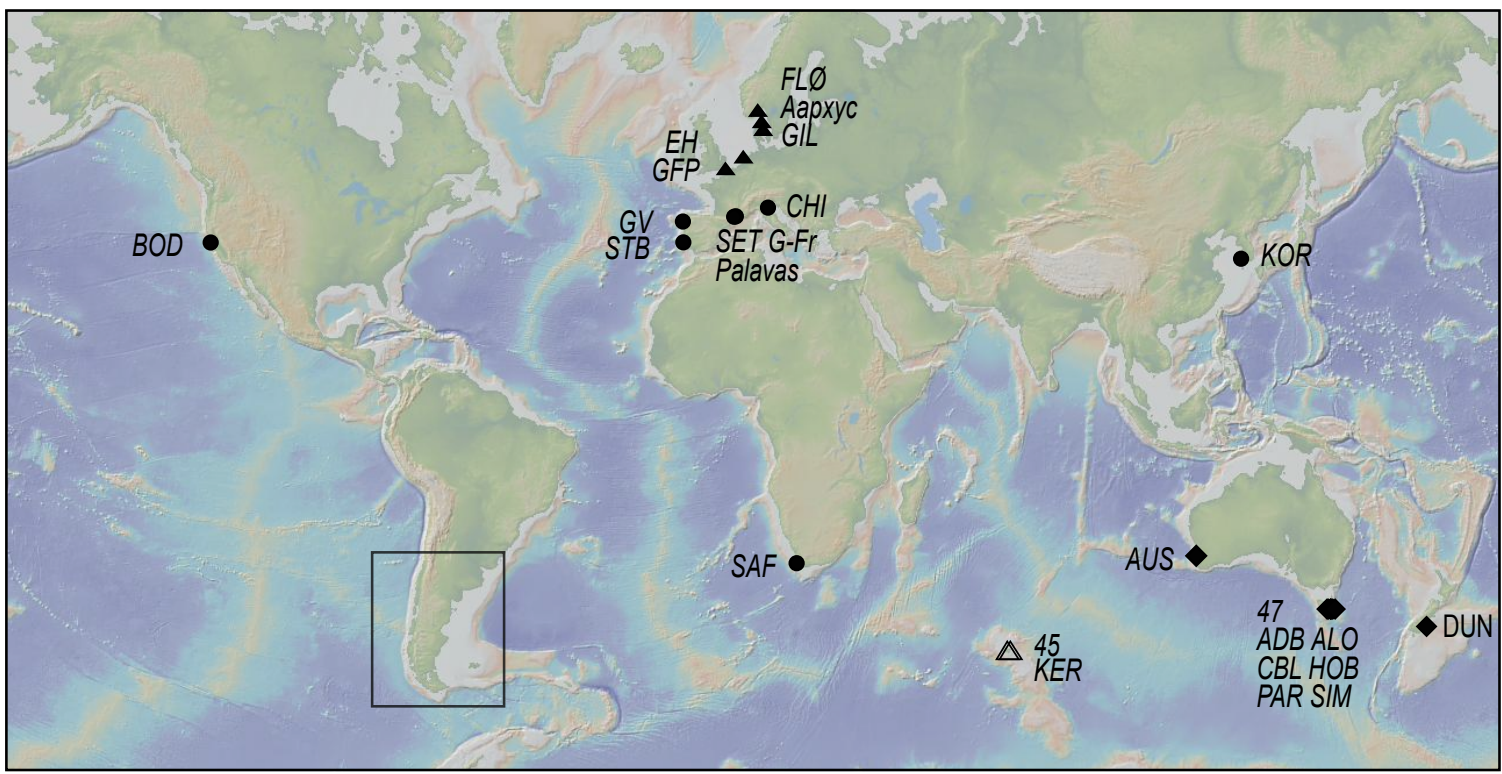

B

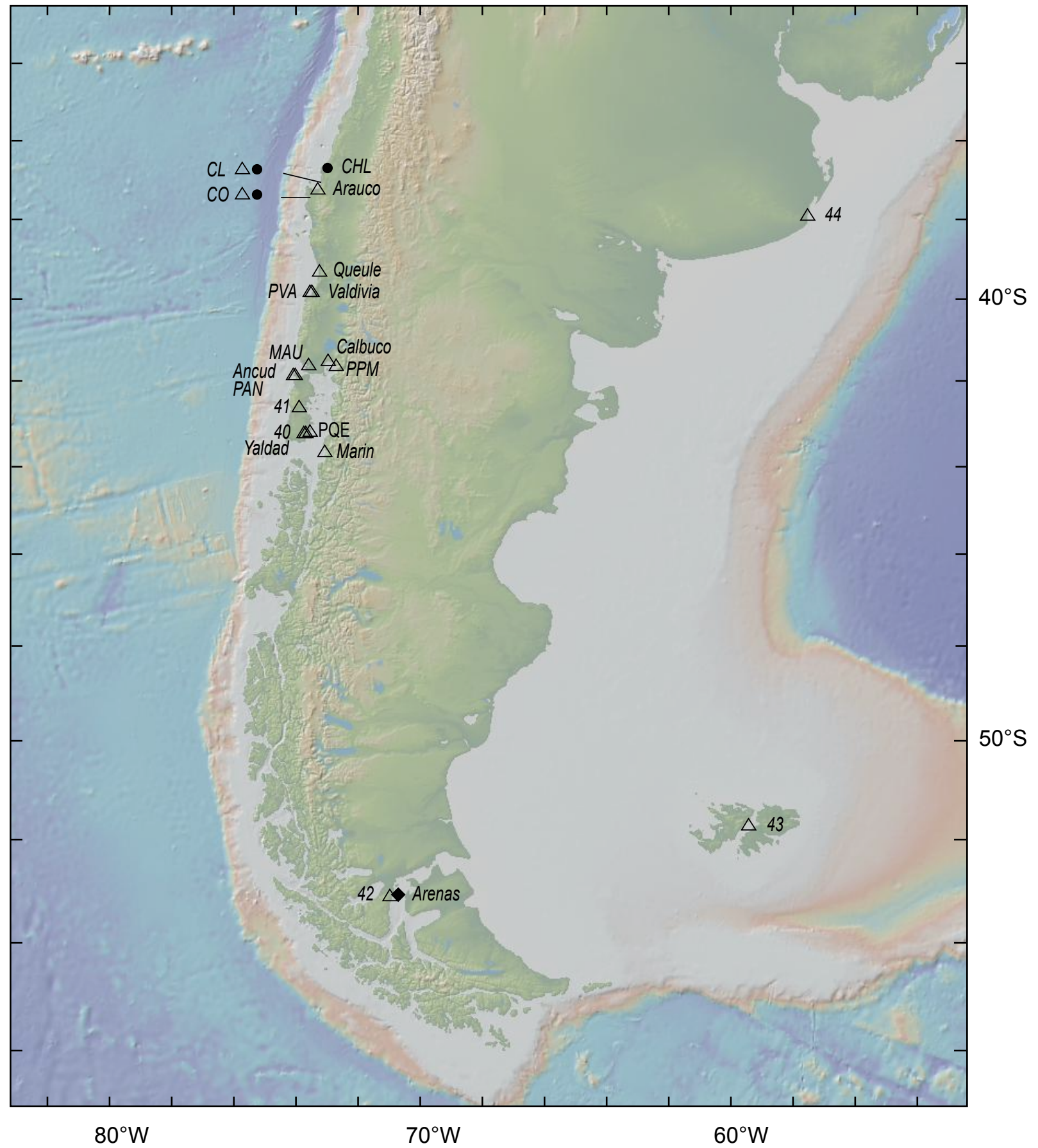



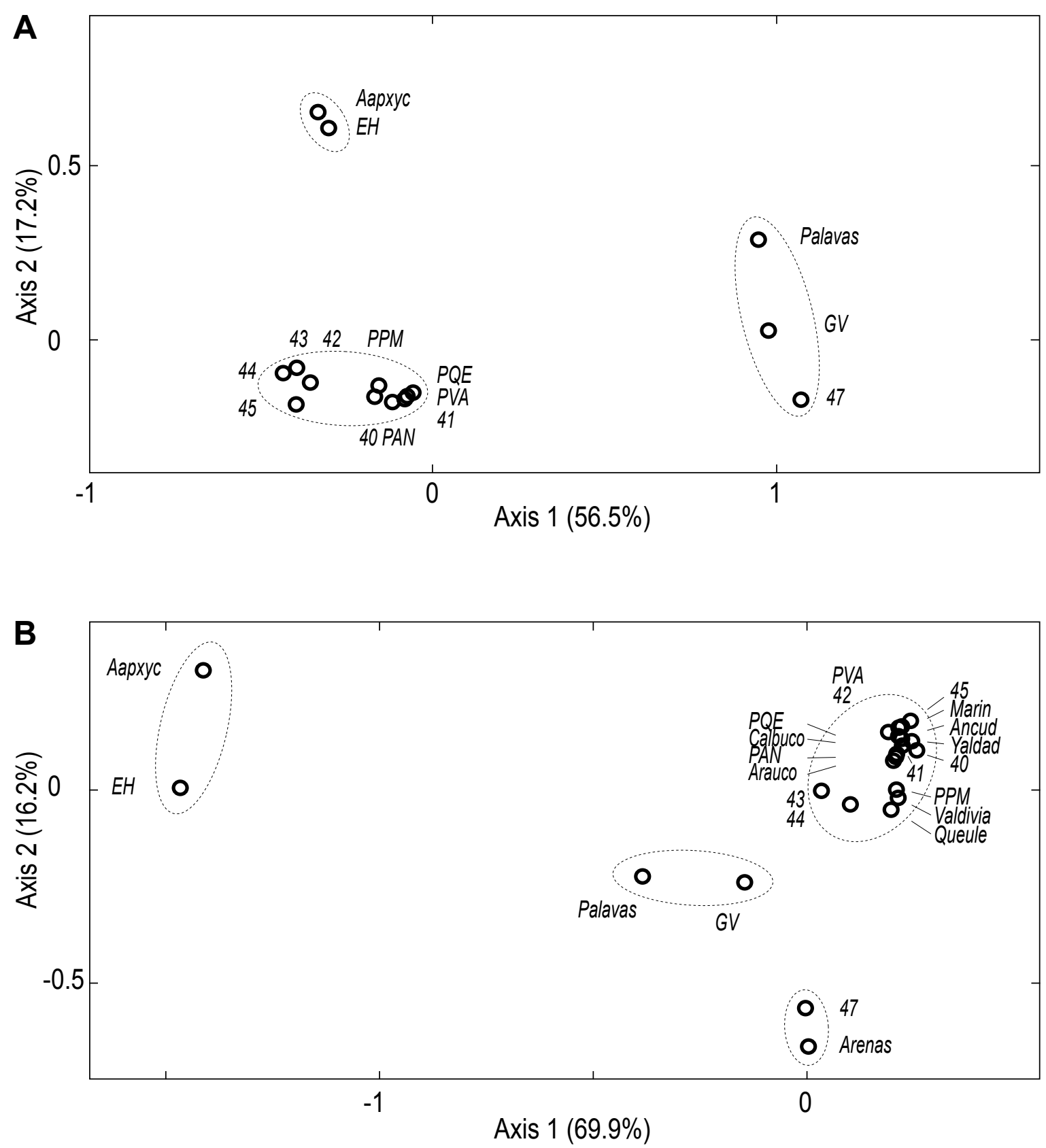


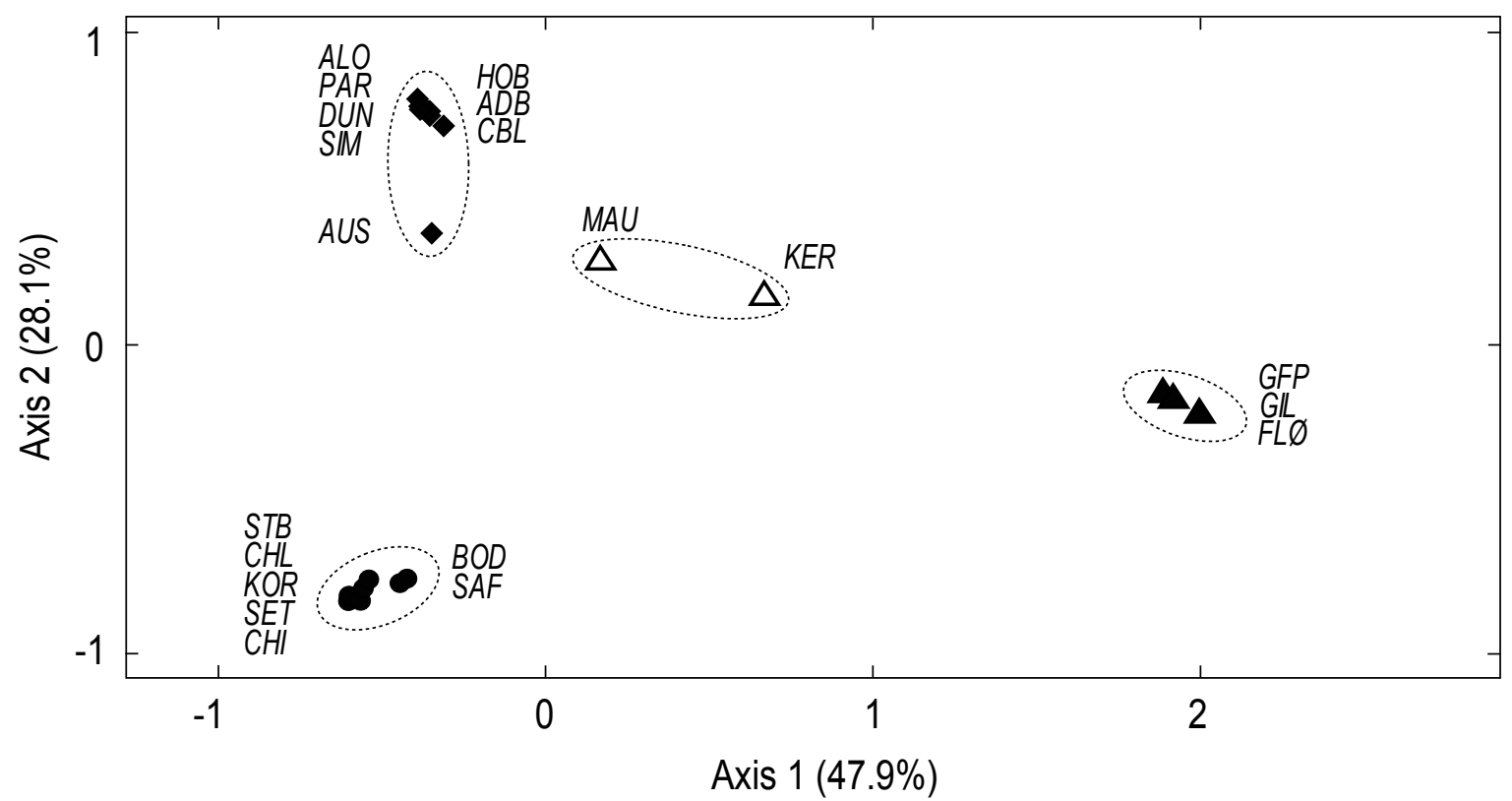




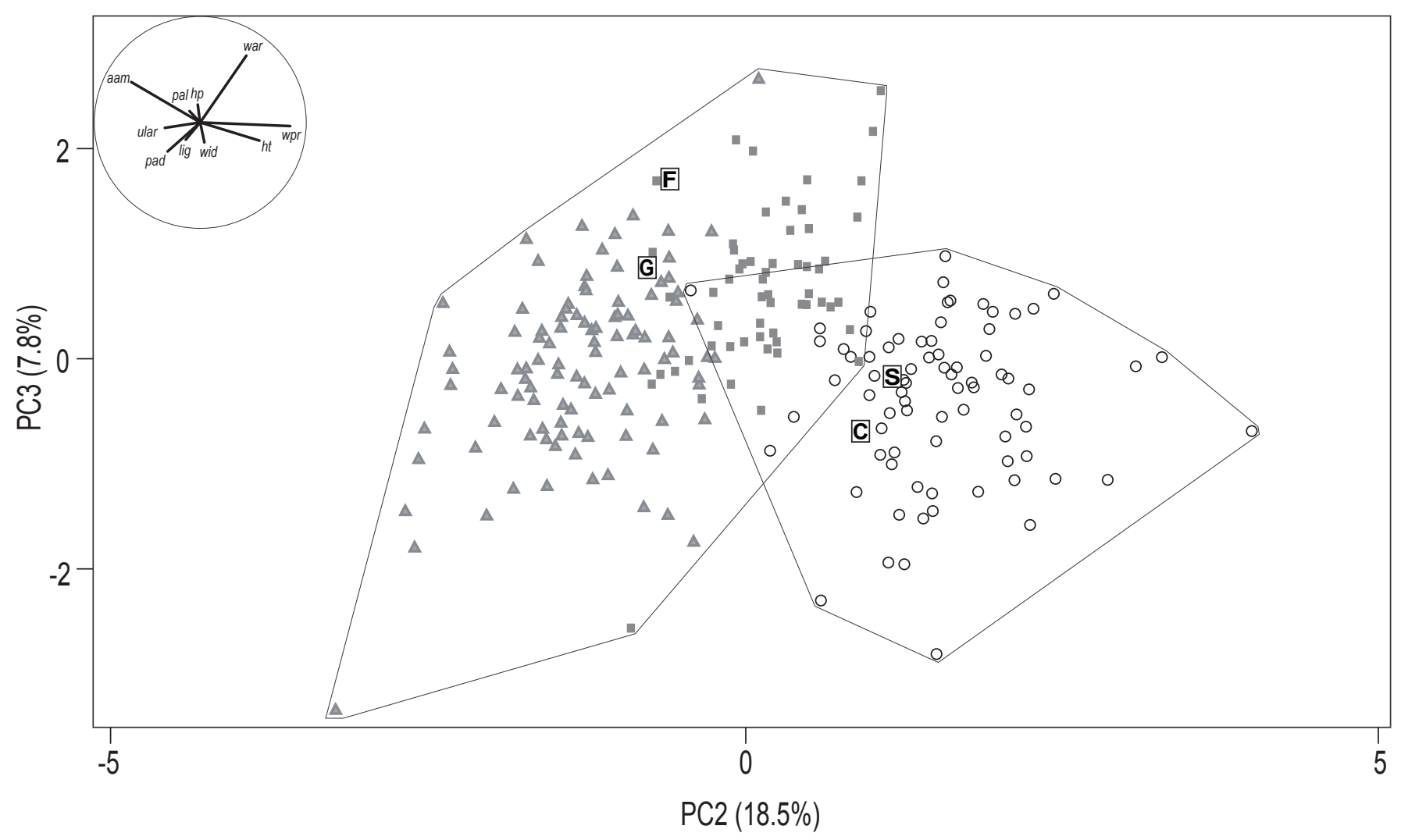




\section{Appendix 1}

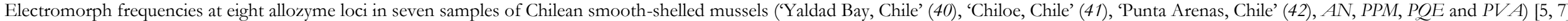
compared with three samples of Southern-Hemisphere Mytilus edulis ('Mar del Plata, Argentina' (44), 'Falkland Islands' (43) and 'Kerguelen Islands' (45)) [5]. Homology of electromorphs between [5] and [26] at loci $A p$, Gpi, Lap, Mpi, Odh and Pgm has been established previously [22], and a similar procedure was followed here for locus Aap ('Lap-1' of [26]). Homology of electromorphs between [5, 26] and [7] were uncovered by comparing samples EH and GV [7] with, respectively, Aapxyc [23] (='Aarhus, Denmark' [5]) and Palavas [26] on the basis of relative migrations and similarities in frequencies; when uncertainty about identity remained, electromorphs were pooled as indicated ('+', ‘ $\leq$ ', ' $\geq$ '). To complete the Aapxyc sample [23], electromorph frequencies at locus Pgm were taken from the geographically close SWED sample [24]. Sample sizes in brackets.

\begin{tabular}{|c|c|c|c|c|c|c|c|c|c|c|c|c|c|c|c|c|c|}
\hline \multicolumn{3}{|l|}{$\begin{array}{l}\text { Locus, } \\
\text { electromorph }\end{array}$} & \multicolumn{15}{|c|}{ Sample } \\
\hline [5] & {$[7]$} & [26] & 40 & 41 & 42 & 43 & 44 & 45 & 47 & $P A N$ & $P V A$ & $P P M$ & $P Q E$ & Aapxyc & $E H$ & Palavas & $G V$ \\
\hline Aap & $L_{a p}-1$ & Lap-1 & (25) & (23) & $(25)$ & (25) & (25) & $(22)$ & (23) & (41) & (60) & (71) & (71) & (11) & $(65)$ & (93) & (38) \\
\hline$\leq 95$ & $93+96$ & 2 & 0.36 & 0.28 & 0.48 & 0.74 & 0.52 & 0.76 & - & 0.34 & 0.27 & 0.26 & 0.24 & 0.14 & 0.21 & 0.01 & - \\
\hline 100 & 100 & 3 & 0.62 & 0.68 & 0.44 & 0.26 & 0.48 & 0.24 & 0.02 & 0.66 & 0.68 & 0.68 & 0.73 & 0.76 & 0.76 & 0.06 & - \\
\hline 105 & 102 & 4 & 0.02 & 0.02 & 0.04 & - & . & - & - & - & - & 0.02 & 0.01 & 0.10 & 0.01 & 0.09 & - \\
\hline 110 & 104 & 5 & - & 0.02 & 0.04 & - & - & - & 0.15 & - & 0.05 & 0.02 & 0.02 & - & 0.02 & 0.41 & 0.49 \\
\hline $115+120$ & $\geq 108$ & $6+7$ & - & - & - & - & - & - & 0.83 & - & - & 0.01 & - & - & 0.01 & 0.43 & 0.51 \\
\hline$A p$ & $A p-1$ & $A p$ & (25) & (23) & (25) & (25) & (25) & (22) & (23) & (41) & (59) & (69) & (72) & (11) & (71) & (92) & (70) \\
\hline $90+95$ & $93+96$ & $1+2$ & - & - & 0.08 & 0.04 & 0.06 & - & - & 0.01 & 0.01 & 0.01 & 0.01 & 0.08 & 0.02 & 0.01 & 0.01 \\
\hline 100 & 100 & 3 & 0.54 & 0.52 & 0.72 & 0.70 & 0.58 & 0.86 & 0.19 & 0.62 & 0.54 & 0.66 & 0.53 & 0.64 & 0.72 & 0.18 & 0.38 \\
\hline 103 & 104 & 4 & - & - & - & - & - & - & - & - & 0.01 & - & - & 0.02 & 0.01 & - & - \\
\hline 105 & 108 & 5 & 0.42 & 0.33 & 0.18 & 0.22 & 0.30 & 0.12 & 0.23 & 0.29 & 0.33 & 0.30 & 0.40 & 0.22 & 0.22 & 0.47 & 0.46 \\
\hline 108 & 114 & 6 & 0.04 & 0.11 & 0.02 & 0.04 & 0.06 & 0.02 & 0.56 & 0.06 & 0.09 & 0.03 & 0.07 & - & 0.04 & 0.16 & 0.13 \\
\hline $117+120$ & $122+128$ & $7+8$ & - & 0.04 & - & - & - & - & 0.02 & 0.01 & 0.02 & 0.01 & - & - & - & 0.18 & 0.03 \\
\hline Est & Est-D & Est-D & $(25)$ & (23) & $(25)$ & $(25)$ & (25) & $(22)$ & (23) & (41) & (61) & (71) & (71) & (11) & $(75)$ & (99) & (72) \\
\hline 80 & 82 & 1.2 & - & - & - & - & - & - & 0.02 & - & - & - & - & -- & - & 0.04 & 0.04 \\
\hline 90 & 90 & 4 & 0.30 & 0.59 & 0.08 & - & - & - & 0.48 & 0.62 & 0.57 & 0.45 & 0.63 & 0.04 & 0.01 & 0.94 & 0.91 \\
\hline$\geq 100$ & $\geq 100$ & $\geq 6$ & 0.70 & 0.41 & 0.92 & 1.00 & 1.00 & 1.00 & 0.50 & 0.38 & 0.43 & 0.55 & 0.37 & 0.96 & 0.99 & 0.02 & 0.06 \\
\hline Gpi & $G p i$ & $P g i$ & (25) & (23) & (25) & (25) & (25) & (22) & (23) & (41) & (58) & (70) & (69) & (11) & (75) & (94) & (66) \\
\hline$\leq 96$ & $\leq 98$ & $1+2$ & - & 0.02 & 0.14 & 0.12 & 0.26 & 0.10 & 0.12 & 0.11 & 0.13 & 0.05 & 0.21 & 0.20 & 0.07 & 0.01 & 0.06 \\
\hline $98+100+102$ & $100+102+105$ & $3+4+5$ & 1.00 & 0.98 & 0.86 & 0.84 & 0.74 & 0.90 & 0.85 & 0.89 & 0.87 & 0.95 & 0.79 & 0.26 & 0.38 & 0.82 & 0.85 \\
\hline$\geq 105$ & $\geq 107$ & $\geq 6$ & - & - & - & 0.04 & - & - & 0.02 & - & - & - & - & 0.54 & 0.55 & 0.18 & 0.09 \\
\hline Lap & Lap-2 & Lap-2 & (25) & (23) & (25) & (25) & (25) & (22) & (23) & (41) & (59) & (71) & (72) & (11) & (72) & (100) & (68) \\
\hline $92+94$ & $90+95$ & $1+2$ & 0.16 & 0.15 & 0.38 & 0.32 & 0.28 & 0.10 & 0.12 & 0.17 & 0.25 & 0.28 & 0.24 & 0.08 & 0.17 & 0.03 & 0.10 \\
\hline 96 & 100 & 3 & 0.82 & 0.81 & 0.62 & 0.68 & 0.72 & 0.90 & 0.79 & 0.82 & 0.75 & 0.68 & 0.73 & 0.70 & 0.58 & 0.46 & 0.54 \\
\hline
\end{tabular}




\begin{tabular}{|c|c|c|c|c|c|c|c|c|c|c|c|c|c|c|c|c|c|}
\hline $98+100$ & $\geq 102$ & $5+7$ & 0.02 & 0.04 & - & - & - & - & 0.08 & 0.01 & 0.01 & 0.04 & 0.03 & 0.22 & 0.25 & 0.51 & 0.36 \\
\hline Mpi & $M p i$ & $M p i$ & (25) & (23) & $(25)$ & $(25)$ & $(25)$ & $(22)$ & (23) & $(40)$ & (59) & (68) & (70) & (11) & (59) & $(75)$ & (56) \\
\hline $90+92$ & $25+100$ & 2 & 0.22 & 0.24 & 0.12 & - & 0.06 & 0.02 & 0.96 & 0.26 & 0.36 & 0.16 & 0.4 & 0.06 & 0.02 & 0.97 & 0.97 \\
\hline $96+100$ & 200 & 3 & 0.78 & 0.76 & 0.88 & 1.00 & 0.88 & 0.98 & 0.04 & 0.73 & 0.64 & 0.84 & 0.6 & 0.94 & 0.98 & 0.03 & 0.03 \\
\hline 110 & 300 & - & - & - & - & - & 0.06 & - & - & 0.01 & - & - & - & - & 0.01 & - & - \\
\hline$O d h$ & $O d h$ & $O d h$ & (25) & (23) & (25) & (25) & (25) & (22) & (23) & (31) & (58) & (68) & (37) & (11) & (64) & (99) & (35) \\
\hline $80+90$ & $80+100$ & $1+3$ & 0.14 & 0.07 & 0.08 & 0.02 & 0.02 & 0.16 & 0.59 & 0.03 & 0.02 & 0.13 & 0.01 & - & 0.06 & 0.15 & 0.49 \\
\hline$\geq 98$ & $\geq 112$ & $\geq 4$ & 0.86 & 0.93 & 0.92 & 0.98 & 0.98 & 0.84 & 0.42 & 0.97 & 0.98 & 0.86 & 0.99 & 1.00 & 0.95 & 0.86 & 0.52 \\
\hline Pgm & $P g m-2$ & Pgm & (25) & (23) & $(25)$ & $(25)$ & $(25)$ & $(22)$ & (23) & (37) & (55) & (71) & (72) & (66) & (74) & $(96)$ & (73) \\
\hline$\leq 93$ & $\leq 96$ & $\leq 3$ & 0.02 & - & - & 0.04 & 0.06 & - & 0.29 & 0.03 & - & 0.06 & 0.01 & 0.09 & 0.19 & 0.17 & 0.15 \\
\hline 100 & 100 & 4 & 0.88 & 0.80 & 0.82 & 0.54 & 0.56 & 0.90 & 0.69 & 0.82 & 0.84 & 0.80 & 0.84 & 0.70 & 0.57 & 0.57 & 0.55 \\
\hline$\geq 106$ & $\geq 102$ & $\geq 6$ & 0.10 & 0.20 & 0.18 & 0.42 & 0.38 & 0.10 & 0.02 & 0.15 & 0.16 & 0.15 & 0.15 & 0.21 & 0.24 & 0.27 & 0.30 \\
\hline
\end{tabular}




\section{Appendix 2}

Electromorph frequencies at two allozyme loci in eight samples of Chilean smooth-shelled mussels analyzed by [10]. Homology of electromorphs between [5] and [10] was established as indicated in Section 2 ("Materials and Methods"). Sample sizes in brackets.

\begin{tabular}{|c|c|c|c|c|c|c|c|c|c|}
\hline \multicolumn{2}{|c|}{$\begin{array}{l}\text { Locus, } \\
\text { electromorph }\end{array}$} & \multicolumn{8}{|l|}{ Sample } \\
\hline [5] & [10] & Arauco & Queule & Valdivia & Calbuco & Ancud & Yaldad & Marin & Arenas \\
\hline Gpi & GPI & (112) & (80) & (102) & (110) & $(110)$ & (111) & (99) & (107) \\
\hline$\leq 96$ & $A$ & 0.11 & 0.03 & 0.03 & 0.10 & 0.10 & 0.07 & 0.13 & 0.13 \\
\hline$\geq 98$ & $B+C$ & 0.88 & 0.97 & 0.97 & 0.90 & 0.91 & 0.93 & 0.87 & 0.87 \\
\hline Pgm & $P G M$ & (109) & (108) & (116) & (110) & (99) & (128) & (99) & (100) \\
\hline$\leq 93$ & $A$ & 0.03 & 0.07 & 0.06 & 0.02 & 0.01 & 0.01 & 0.01 & 0.30 \\
\hline 100 & $B$ & 0.80 & 0.75 & 0.78 & 0.79 & 0.83 & 0.80 & 0.84 & 0.47 \\
\hline$\geq 106$ & $C+D$ & 0.18 & 0.19 & 0.16 & 0.20 & 0.16 & 0.20 & 0.16 & 0.25 \\
\hline
\end{tabular}


Appendix 3

Allelomorph frequencies at nuclear-DNA loci mac-1and Glu-5' in 20 samples of smooth-shelled Mytilus spp. including two samples collected in Chile (CHL, $M A U$ ). Size homologies between allelomorphs from different samples were ascertained by side-by-side electrophoretic runs. mac-1 allelomorph nomenclature follows [33]; Glu-5' allelomorphs $G$, E and E' [29] are allelomorphs 300, 350 and 380,

respectively, in [34]; reference samples from the Northern Hemisphere (FLO, GIL, STB, SET, CHI) from [16, 22, 29, 32]. N, sample size.

\begin{tabular}{|c|c|c|c|c|c|c|c|c|c|c|c|c|c|c|c|c|c|c|c|c|}
\hline \multirow{2}{*}{$\begin{array}{l}\text { Locus, } \\
\text { Allelomorph }\end{array}$} & \multicolumn{20}{|c|}{ Sample } \\
\hline & FLØ & GIL & GFP & STB & SET & $\mathrm{CHI}$ & $S A F$ & KER & AUS & $A D B$ & $A L O$ & CBL & $H O B$ & $P A R$ & SIM & KOR & DUN & $B O D$ & $\mathrm{CHL}$ & $M A U$ \\
\hline \multicolumn{21}{|l|}{ mac-1 } \\
\hline$f 1$ & - & - & - & 0.02 & - & - & 0.02 & - & - & - & - & - & - & - & - & - & - & - & - & - \\
\hline$f_{2}$ & - & - & - & - & - & - & 0.01 & - & - & - & - & - & - & - & - & - & - & - & - & - \\
\hline f3 & - & - & - & - & - & - & 0.01 & - & - & - & - & - & - & - & - & - & - & - & 0.01 & - \\
\hline$b 0$ & - & - & - & - & - & - & 0.01 & - & - & - & - & - & - & - & - & - & - & - & - & - \\
\hline$b 05$ & - & - & - & - & - & - & - & - & - & - & - & - & - & - & - & - & 0.02 & - & - & - \\
\hline$b 2$ & - & - & - & 0.04 & 0.05 & - & 0.04 & - & - & - & - & - & - & - & - & 0.02 & - & 0.04 & 0.05 & - \\
\hline$b 1$ & - & - & 0.01 & 0.15 & 0.21 & 0.28 & 0.09 & - & 0.04 & - & - & - & - & - & - & 0.42 & - & 0.32 & 0.32 & - \\
\hline$b 3$ & - & - & - & - & - & - & - & - & - & - & - & - & - & - & - & 0.02 & - & - & 0.01 & - \\
\hline$b 4$ & - & - & - & 0.02 & - & 0.01 & - & - & - & - & - & - & - & - & - & - & - & - & - & - \\
\hline$b 5$ & - & - & - & 0.02 & - & - & - & - & - & - & - & - & - & - & - & - & - & - & - & - \\
\hline$c 1$ & - & - & 0.01 & 0.10 & 0.07 & 0.06 & 0.10 & - & - & - & - & - & - & - & - & 0.05 & - & 0.04 & 0.08 & - \\
\hline$c 12$ & - & - & - & - & - & - & - & - & - & - & - & - & - & - & - & - & - & - & 0.01 & - \\
\hline$c 15$ & - & - & - & - & - & - & 0.01 & - & - & - & - & - & - & - & - & - & - & - & - & - \\
\hline$c 2$ & - & - & - & 0.50 & 0.54 & 0.57 & 0.53 & - & 0.16 & - & - & - & - & - & - & 0.43 & - & 0.41 & 0.39 & - \\
\hline$c 3$ & - & - & - & 0.02 & - & 0.01 & 0.04 & - & - & - & - & - & - & - & - & - & - & - & 0.01 & - \\
\hline$c 4$ & 0.05 & - & 0.02 & - & - & - & - & 0.08 & - & - & - & - & - & - & - & - & - & - & - & - \\
\hline$c 6$ & - & - & - & - & 0.01 & - & 0.01 & - & - & - & - & - & - & - & - & - & - & 0.01 & - & - \\
\hline$a 0$ & 0.02 & - & - & - & - & - & - & - & - & - & - & - & - & - & - & - & - & - & - & - \\
\hline$a 0.5$ & - & - & - & - & - & - & - & - & - & - & 0.01 & - & - & - & - & - & 0.04 & - & - & - \\
\hline a1 & 0.06 & 0.02 & 0.01 & 0.02 & - & - & - & - & - & - & - & 0.03 & - & - & - & - & - & - & - & - \\
\hline$a 15$ & - & - & - & - & - & - & - & - & 0.01 & - & - & - & - & - & - & - & 0.01 & - & - & - \\
\hline$a 2$ & 0.10 & 0.15 & 0.20 & 0.02 & - & - & 0.02 & 0.20 & 0.62 & 0.95 & 0.99 & 0.92 & 0.98 & 1.00 & 0.99 & 0.02 & 0.92 & - & 0.03 & 0.26 \\
\hline$a^{3}$ & 0.29 & 0.31 & 0.24 & 0.04 & 0.01 & - & 0.03 & 0.70 & 0.16 & 0.04 & - & 0.03 & - & - & 0.01 & - & 0.02 & 0.03 & - & 0.74 \\
\hline a4 & 0.07 & 0.17 & 0.18 & - & - & - & - & 0.01 & - & - & - & 0.02 & 0.02 & - & - & - & - & - & 0.01 & - \\
\hline$a_{5}$ & 0.38 & 0.27 & 0.29 & - & - & - & 0.02 & - & - & - & - & - & - & - & - & - & - & 0.10 & 0.01 & - \\
\hline$a 6$ & - & 0.08 & 0.04 & - & 0.01 & - & 0.02 & - & 0.01 & - & - & - & - & - & - & - & - & - & 0.01 & - \\
\hline
\end{tabular}




\begin{tabular}{|c|c|c|c|c|c|c|c|c|c|c|c|c|c|c|c|c|c|c|c|c|}
\hline a7 & - & - & - & 0.02 & 0.04 & 0.03 & 0.04 & - & - & - & - & - & - & - & - & 0.03 & - & 0.01 & 0.03 & - \\
\hline$a 8$ & - & - & - & 0.04 & 0.06 & 0.03 & 0.01 & - & - & - & - & - & - & - & - & 0.02 & - & 0.01 & 0.05 & - \\
\hline a9 & 0.01 & - & - & - & - & - & - & - & - & - & - & - & - & - & - & - & - & - & - & - \\
\hline$d$ & 0.01 & - & - & - & - & - & - & - & - & - & - & - & - & - & - & - & - & - & - & - \\
\hline$(N)$ & $(47)$ & (26) & $(42)$ & $(26)$ & $(68)$ & $(47)$ & $(62)$ & (83) & $(38)$ & $(28)$ & $(59)$ & $(32)$ & $(31)$ & $(30)$ & $(40)$ & $(30)$ & $(79)$ & (34) & $(76)$ & (51) \\
\hline \multicolumn{21}{|l|}{ Glu-5' } \\
\hline$E+E^{\prime}+E^{\prime \prime}+i$ & 1.00 & 1.00 & 1.00 & - & 0.01 & - & 0.05 & 0.35 & - & - & - & - & - & - & - & - & - & - & - & - \\
\hline$G+i+i i$ & - & - & - & 1.00 & 0.99 & 1.00 & 0.95 & 0.65 & 1.00 & 1.00 & 1.00 & 1.00 & 1.00 & 1.00 & 1.00 & 1.00 & 1.00 & 0.98 & 1.00 & 1.00 \\
\hline$T$ & - & - & - & - & - & - & - & - & - & - & - & - & - & - & - & - & - & 0.02 & - & - \\
\hline$(N)$ & (35) & (16) & (42) & (19) & (56) & (18) & $(65)$ & $(79)$ & $(46)$ & (26) & $(25)$ & (29) & (26) & (25) & (38) & (19) & (77) & (23) & (48) & (28) \\
\hline
\end{tabular}

